\title{
MODEL MANAJEMEN RANTAI PASOKAN PADA START UP BUSINESS
}

\author{
Romauli Nainggolan \\ Program Studi Manajemen, Universitas Ciputra \\ Email : roma_ps@yahoo.com
}

\begin{abstract}
Supply chain management in a beginner business is simple, not as complex when compared to the supply chain of large and developed businesses. This study will describe the supply chain management model of the start-up business owned by Ciputra University students. In addition, this study will expose the strategy of supply of raw materials from suppliers. Sample in this study were 30 start-up businesses that have been operating for more than 2 years, with the type of business being Food and Beverage. From the results of the study there are 2 findings, namely 1) There are only 3 types of supply chain management at businesses owned by UC students. Model 1, namely Supplier - Manufacturer - Consumer. Model 2 being Supplier Manufacturer - Retailer - Consumer. Model 3 is Supplier - Distributor - Consumer. 2) In terms of providing raw materials, at most 30\% of start-up businesses use few supplier strategy with 3 suppliers. Then, at least 16.6\% of startup businesses use many suppliers with 5 suppliers. The majority of these start-up business owners purchase raw materials from the nearest markets, shops and supermarkets to facilitate the outreach of raw material supply.
\end{abstract}

Keywords : Start-Up Business, Supply Chain Model, Strategy, Supplier, Consumers

\begin{abstract}
ABSTRAK
Manajemen rantai pasokan pada bisnis pemula masih sederhana, tidak sekompleks dibandingkan dengan mata rantai pasokan bisnis besar dan maju. Penelitian ini akan memaparkan model manajemen rantai pasokan bisnis startup milik mahasiswa Univeristas Ciputra. Selain itu, penelitian ini akan menunjukkan strategi persediaan bahan baku dari pemasok. Sample dalam penelitian ini sebanyak 30 bisnis start up yang telah beroperasi lebih dari 2 tahun, dengan jenis usaha Food and Beverage. Dari hasil penelitian ada 2 temuan yaitu 1) Hanya ada 3 model manajemen rantai pasokan bisnis start up milik mahasiswa UC. Model 1 yaitu Supplier - Manfukatur - Konsumen. Model 2 yaitu Supplier - Manfukatur - Pengecer - Konsumen. Model 3 yaitu Supplier - Distributor - Konsumen. 2) Dalam hal penyediaan bahan baku, paling banyak ada $30 \%$ bisnis start up menggunakan strategi sedikit pemasok dengan 3 pemasok. Kemudian paling sedikit ada $16,6 \%$ bisnis start up menggunakan starategi banyak supplier dengan 5 pemasok. Mayoritas pemilik usaha start up ini membeli bahan baku dari pasar, toko dan supermarket terdekat untuk memudahkan penjangkauan penyediaan bahan baku.
\end{abstract}

Kata kunci : bisnis start up, model rantai pasokan, strategi

\section{PENDAHULUAN}

\section{Latar Belakang}

Saat ini pemerintah memberi perhatian penuh bagi kewirausahaan baru. Beberapa pihak perbankan dan pemerintah mendukung tumbuh majunya wirausaha muda. Misalnya Bank mandiri yang konsisten menciptakan para wirausahawan baru dengan memberi modal kerja dan bekerjasama dengan pihak kampus sebagai lembaga pendidikan yang menghasilkan pebisnis pemula. Bank BRI yang memberi dukungan berupa pinjaman modal bagi usaha kecil, sering dikenal dengan KUR. Harapannya adalah sektor bisnis baru memberikan kontribusi pada pertumbuhan ekonomi karena berkaitan dengan menurunnya tingkat pengangguran dan terciptanya lapangan kerja. Seorang pengiat kewirausahaan bernama David McCleland mengemukakan bahwa jika ada sebesar 2\% dari seluruh penduduk suatu Negara menjadi entrepreneur akan meningkatkan kemakmuran Negara tersebut. Data di Negara AS pada tahun 1993 ada 2,14 \% entrepreneur, di Negara Singapura pada tahun 2005 ada 7,2 \% entrepreneur. Di Indonesia 
pada tahun 2016 Indonesia ada1,6\% pelaku wirausaha dari total jumlah penduduk 250 juta jiwa ( HIPMI, 2016).

Oleh karena itu, banyak perguruan tinggi negeri maupun swasta yang membuka jurusan kewirausahaan, bertujuan menciptakan sarjana sarjana yang siap membuka lapangan kerja baru dengan berbisnis. Salah satunya di Universitas Ciputra Surabaya, setiap tahun mampu menciptakan 200 usaha baru yang didirikan oleh mahasiswa. Karena semua mahasiswa di perguruan tinggi ini diwajibkan untuk memiliki bisnis. Kurangnya pemahaman tentang manajemen rantai pasokan sering memunculkan berbagai masalah seperti meningkatnya biaya transportasi, biaya persediaan dan biaya resource. Selain itu, kurangnya pemahaman terhadap pentingnya manajemen rantai pasokan dalam perusahaan membuat respon waktu yang sangat lama barang produksi sampai ke tangan konsumen. Masalah masalah utama dalam rantai pasokan terkait dengan: 1) menentukkan tingkat outsourcing yang tepat, 2) mengelola pembelian atau pengadaan suatu barang, 3) mengelola pemasok, 4) mengelola hubungan terhadap pelanggan, 5) mengindentifikasi masalah dan merespon masalah dengan cepat mengelola resiko (Stevenson, 2009).

Untuk mengatasi masalah ini, mahasiswa perlu mengatur rantai pasokan pada masing masing perusahaan. Ada 5 (lima) pelaku dalam rantai pasokan yang perlu diketahui oleh pemilik bisnis pemula yaitu supplier, manufacture, distributor, retailer dan konsumen. Dimana ada 2 aliran yang terjadi dalam rantai pasokan yaitu aliran barang/jasa dan aliran uang. Sekalipun mata rantai dalam bisnis pemula kebanyakan masih pendek namun kolaborasi antara pemasok dengan perusahaan, distributor, retailer, dan pelanggan memungkinkan usaha pemula mengelola aliran bahan, produk, dan juga informasi secara efisien. Tidak sedikit mahasiswa ini mengalami masalah dalam pengelolaan pembelian atau pengadaan suatu barang dan mengelola pemasok. Oleh karena itu, penelitian ini akan mengamati model manajemen rantai pasokan pada startup bisnis milik mahasiswa Universitas Ciputra yang telah di implementasikan selama ini. Selanjutnya, penelitian ini akan mengamati strategi manajemen rantai pasokan terhadap persediaan bahan baku dari spullier.

\section{Kajian pustaka}

Dalam kajian pustaka akan memaparkan kajian empiris dan kajian teoritis. Penelitian yang dilakukan Fajarwati (2015) tentang model manajemen rantai pasokan UKM daerah Yogyakarta yang menganalisis model rantai pasokan UKM UKM selama ini diimplementasikan. Hasil penelitian menunjukkan strategi manajemen rantai pasokan yang digunakan oleh UKM di Yogyakarta dalam menentukan suplier yaitu UKM di Yogyakarta yang menggunakan strategi sedikit suplier dengan 1 suplier yaitu 69,66\%, UKM di Yogyakarta yang menggunakan strategi sedikit suplier dengan 2 suplier yaitu 18,73\%, UKM di Yogyakarta yang menggunakan strategi sedikit suplier dengan 3 suplier yaitu 6,74\%, UKM di Yogyakarta yang menggunakan strategi banyak suplier dengan 4 10 suplier yaitu $4,86 \%$. Dalam penyediaan bahan baku produknya, hampir semua UKM membeli sendiri-sendiri bahan bakunya yang diperoleh dari pasar, toko maupun warung di sekitar tempat tinggalnya. Model manajemen rantai pasokan UKM ini yaitu perusahaan memperoleh bahan baku langsung kemudian melakukan proses manufaktur dengan membuat produk dan langsung menjualnya kepada konsumen atau menjualnya ke distributor, agen, kemudian ke pengecer baru ke konsumen.

Pingkan O.E. Talumewo, Lotje Kawet, Jessy J. Pondaag (2014), menganalisis rantai pasok ketersediaan bahan baku di Industri Jasa Makanan Cepat Saji Pada KFC. Masalah yang muncul yaitu seringkali konsumen mendapati pilihan menu makanan atau minuman yang akan mereka pesan habis terjual atau kosong, padahal KFC menyediakan makanan atau minuman tersebut. Di sinilah peran manajemen rantai pasok terhadap persediaan 
bahan baku di KFC. Hasil penelitian menunjukkan manajemen rantai pasokan berdampak pada persediaan bahan baku yang cukup dan berkualitas. Pihak KFC perlu terus meningkatkan manajemen atau tata kelola rantai pasokan perusahaan agar bahan baku selalu tercukupi dan tersedia kapan saja di butuhkan.

Kajian teoritis berkaitan dengan manajemen rantai pasokan dimulai dari defenisi sederhana. Rantai pasok sebagai sistem yang menggambarkan hubungan antar supplier, manufacturer, distributor dan customer dalam rangka pemenuhan kebutuhan konsumen akhir (Shapiro, 2010). Rantai pasok adalah salah satu bentuk kemitraan strategis antar perusahaan dalam rangka pemenuhan permintaan konsumen dengan ongkos yang minimum. Perlunya kerjasama dan integrasi antar pelaku rantai pasokan. Sehingga manajemen rantai rasokan merupakan pengintegrasian aktifitas pengadaan bahan dan pelayanan, pengubahan menjadi barang setengah jadi dan produk akhir serta pengiriman kepada pelanggan melalui sistem distribusi (Heizer \& Render, 2014). Pendapat lain menyatakan bahwa manajemen rantai pasokan adalah suatu sistem tempat organisasi menyalurkan barang produksi dan jasanya kepada para pelanggannya. Rantai ini juga merupakan jaringan dari berbagai organisasi yang saling berhubungan dan mempunyai tujuan yang sama, yaitu sebaik mungkin menyelenggarakan pengadaan atau barang tersebut. Istilah rantai pasokan meliputi juga proses perubahan barang tersebut, misalnya dari barang mentah menjadi barang jadi (Indrajit \& Djokopranoto, 2009).

Dari berbagai pendapat, maka pengertian manajemen rantai pasokan adalah pengelolaan jaringan dari semua proses bisnis dan kegiatan yang melibatkan pengadaan bahan baku, manufaktur dan manajemen distribusi barang jadi sampai ke tangan konsumen. Manajemen Rantai pasokan juga disebut seni manajemen menyediakan produk yang tepat, tepat waktu, right place pada tempat yang tepat dan tepat harga bagi konsumen. Tujuan yang hendak dicapai dari setiap rantai pasok adalah untuk memaksimalkan nilai yang dihasilkan secara keseluruhan (Chopra, 2004). Tujuan dasar manajemen rantai pasokan adalah untuk mengendalikan persediaan dengan manajemen arus material. Persediaan adalah jumlah material dari pemasok yang digunakan untuk memenuhi permintaan pelanggan atau mendukung proses produksi barang dan jasa. Perusahaan dapat mengambil pendekatan manajemen rantai pasokan yang efisien untuk mengkoordinasikan aliran material untuk meminimalkan persediaan dan memaksimalkan produkivitas perusahaan. Di sisi lain Tujuan rantai pasokan juga menyediakan barang dan jasa dengan tingkat ketersediaan yang tinggi dan memenuhi permintaan dari pelanggan. Akhirnya tujuan dari manajemen rantai pasokan ialah meningkatkan kepercayaan dan kolaborasi diantara rekanan rantai suplai, dan meningkatkan inventaris dalam kejelasannya dan meningkatkan percepatan persediaan.

\section{Pelaku utama manajemen rantai pasokan}

Dalam rantai pasokan ada 5 pelaku utama antara suplier, distributor, manufaktur, retailer, customer. Supplier adalah sumber yang menyediakan bahan pertama, baik bahan baku, bahan penolong, ataupun bahan mentah. Manufaktur adalah yang melakukan pekerjaan membuat, memfabrikasi, merakit, atau melakukan finishing. Distributor adalah penyalur besar. Retailer adalah penyalur lebih kecil yang lebih dekat dengan konsumen. Customer adalah pengguna akhir barang produksi dan jasa. Agar dapat lebih memahami dapat melihat gambar 1. Struktur manajemen rantai pasokan dibawah ini. Lihat gambar 1 dibawah ini. 


\section{Gambar 1. Struktur Manajemen rantai pasokan}

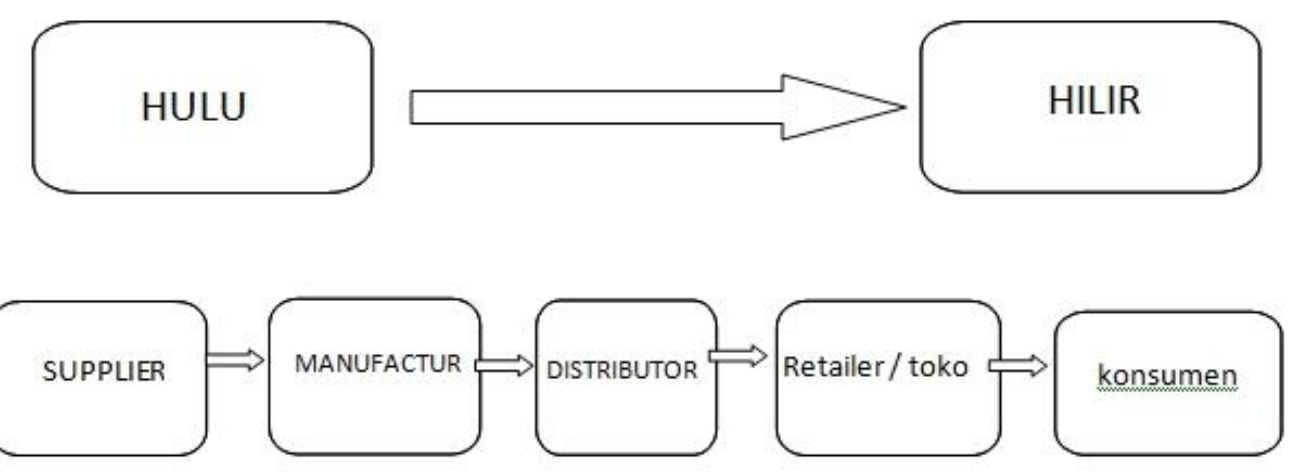

Berkaitan dengan ketersediaan barang yang disediakan supplier bagi manufactur, maka ada strategi rantai pasokan yang harus diperhatikan. Terdapat lima strategi yang dapat dipilih perusahaan untuk melakukan pembelian kepada supplier yaitu adalah sebagai berikut:

1. Banyak Pemasok (Many Supplier)

2. Sedikit Pemasok (Few Supplier)

3. Vertical Integration

4. Kairetsu Network

5. Perusahaan Maya (Virtual Company)

\section{Model manajemen rantai pasokan}

Menurut James dan Fitzsimmons (2006), bentuk fisik dari suatu barang dalam supply chain dapat dilihat sebagai tahapan jaringan nilai tambah bahan pengolahan yang masingmasing didefinisikan dengan pasokan input,transformasi material dan output permintaan. Supplier, manufacturing, distribution, retailing, dan recycling/remanufacturing yang terhubung menggambarkan aliran material dengan saham persediaan antara tiap tahap. Pengiriman informasi ke arah yang berlawanan dilakukan oleh supplier, proses desain produk, dan layanan pelanggan. Tahap pada manufacturing mewakili operasi tradisional yang dimana bahan baku tiba dari pemasok eksternal; material berubah dalam beberapa cara untuk menambah nilai, menciptakan persediaan barang jadi. Tahap pada bagian hilir lainnya seperti distribusi dan ritel juga menambah suatu nilai terhadap material.

\section{Bisnis start up}

Menurut Wikipediabisnis Startup merujuk pada perusahaan yang belum lama beroperasi. Perusahaan-perusahaan ini sebagian besar merupakan perusahaan yang baru didirikan dan berada dalam fase pengembangan dan penelitian untuk menemukan pasar yang tepat. Menurut pendiri dan pengelola 500 perusahaan startup mendefenisikan bahwa Startup bisnis adalah perusahaan yang belum menemukan: target konsumen, produk \& cara menjualnya (David Mc Clure, 2012). Belum ada lembaga atau sebuah perjanjian yang mengatur sebuah perusahaan bisa disebut sebagai startup atau bukan, tapi ada literatur (pendapat) yang bisa di jadikan landasan identifikasinya. Rama Mamuaya, founder DailySocial.net merangkumnya lewat Tekno Jurnal menjadi tiga variabel:

1. Beroperasi (umur) kurang dari tiga tahun

2. Memiliki kurang dari 20 karyawan 
3. Memiliki pendapatan kurang dari $\$ 100.000$ pertahun

Dengan demikian ciri ciri bisnis start up yaitu :

1. Jenis barang/komoditi yang diusahakan umumnya sudah tetap atau tidak gampang berubah.

2. Lokasi/tempat usaha umumnya belum menetap atau masih berpindah-pindah.

3. Pada umumnya administrasi keuangan masih sederhana, keuangan perusahaan masih campur keuangan pribadi atau keluarga.

4. Sumberdaya manusia (pengusaha) memiliki pengalaman dalam berwira usaha.

5. Sebagian kecil sudah akses ke perbankan dalam hal keperluan modal.

6. Sebagian besar belum dapat membuat manajemen usaha dengan baik seperti business.

\section{METODE PENELITIAN}

Penelitian ini merupakan penelitian kualitatif deskriptif dengan mengamati kegiatan rantai pasokan bisnis start up mahasiswa Universitas Ciputra. Pengamatan kegiatan bisnis mulai dari hulu sampai ke hilir kepada 30 bisnis start up mahasiswa UC tidak dilakukan di pabrik ataupun di rumah produksi. Hal ini dikarenakan dapur keluarga di gabung dengan tempat proses produksi. Setiap tahun berdiri 200 kelompok bisnis start up di Universitas Ciputra. Tidak sedikit bisnis tersebut berhenti dijalan karena kegagalan internal. Dari sebagian bisnis yang masih bertahan itulah peneliti akan melakukan pengamatan model manajemen rantai pasokan dengan tahapan penelitian sebagai berikut:

a. Penyusunan riset desain dan quisioner.

b. Identifikasi start up bisnis yang beroperasi di atas 2 tahun dan produk Food and Beverages.

c. Komunikasi dan penjadwalan antara peneliti dan responden.

d. Pengumpulan data lapangan lewat pengisian quisioner dan wawancara.

e. Pengolahan data mulai dengan tabulasi data dan informasi

f. Olah data dengan identifikasi model rantai pasokan

g. Diakhiri dengan pengolahan data dan informasi

\section{Obyek dan subyek penelitian}

Objek dalam penelitian ini adalah bisnis start up Mahasiswa Univeritas Ciputra yang telah beroperasi lebih dari 2 tahun. Pemilik bisnis dijadikan sebagai responden karena dianggap mewakili dan mengetahui keadaan usahanya, terutama mengenai rantai pasokannya dari Supplier sampai ke tangan konsumen. Banyaknya objek pengamatan yaitu 30 bisnis start up food and beverage. Metode penelitian yang digunakan untuk meneliti kondisi obyek yang alamiah dimana peneliti sebagai instrument kunci atau subyek. Obyek yang alamiah ialah obyek yang apa adanya, tidak dimanipulasi oleh peneliti sehingga kondisi pada saat peneliti berada di obyek dan setelah keluar dari obyek relatif tidak berubah (Sugiyono, 2011;115).Teknik pengambilan sampling adalah purposif sampling yaitu pengambilan sampel atau informan berdasarkan kriteria tertentu. Kriteria memilih informan sebagai narasumber dalam penelitian ini yaitu mahasiswa UC sebagai pemilik bisnis startup khususnya perusahaan produksi barang saja dan telah berdiri lebih dari 2 tahun.

Penelitian ini dibatasi untuk start up bisnis dengan kriteria 1) Sudah berdiri lebih dari 2 tahun. 2) Perusahaan yang menghasilkan produksi barang. Hal ini dikarenakan aliran informasi barang dan keuangan lebih mudah dilacak sehingga dengan mudah mengetahui permasalahan yang muncul dalam rantai pasokan. 3) Memiliki kegiatan produksi, operasional, penjualan dan pemasaran yang tetap. 4) Memiliki segment pasar yang jelas. 


\section{Cara pengumpulan data}

Instrumen utama pengumpulan data pada penelitian kualitatif ialah peneliti itu sendiri atau apa yang disebut sebagai human instrument (Bungin, 2001: 71 dan Danim, 2002: 135). Tujuan kualitatif bersifat mendeskripsikan keadaan atau fenomena yang sedang terjadi, oleh sebab itu instrumen diperlukan karena peneliti dituntut dapat menemukan data yang diangkat dari fenomena atau peristiwa tertentu, peneliti dalam melaksanakan wawancara walaupun sifatnya tak terstruktur tetapi minimal peneliti menggunakan pedoman pertanyaan yang akan ditanyakan sebagai catatan, yang disebut sebagai pedoman wawancara.

\section{Definisi operasional}

Manajemen rantai pasokan adalah rangkaian hubungan antar perusahaan atau aktivitas yang melaksanakan penyaluran pasokan barang atau jasa dari tempat asal sampai ke tempat pembeli atau pelanggan. Rantai pasokan menyangkut hubungan yang terusmenerus mengenai barang, uang dan informasi. Barang umumnya mengalir hulu ke hilir,uang mengalir dari hilir ke hulu, sedangkan informasi mengalir baik dari hulu ke hilir maupun hilir ke hulu. Dilihat secara horizontal, ada lima komponen utama atau pelaku dalam rantai pasokan, yaitu supplier (pemasok), manufacturer (pabrik pembuat barang), distributor (pedagang besar), retailer (pengecer), customer (pelanggan). Secara Vertikal, ada lima komponen utama rantai pasokan, yaitu buyer (pembeli), transpoter (pengangkut), warehouse (penyimpan), seller (penjual) dan sebagainya. Lihat gambar 3.

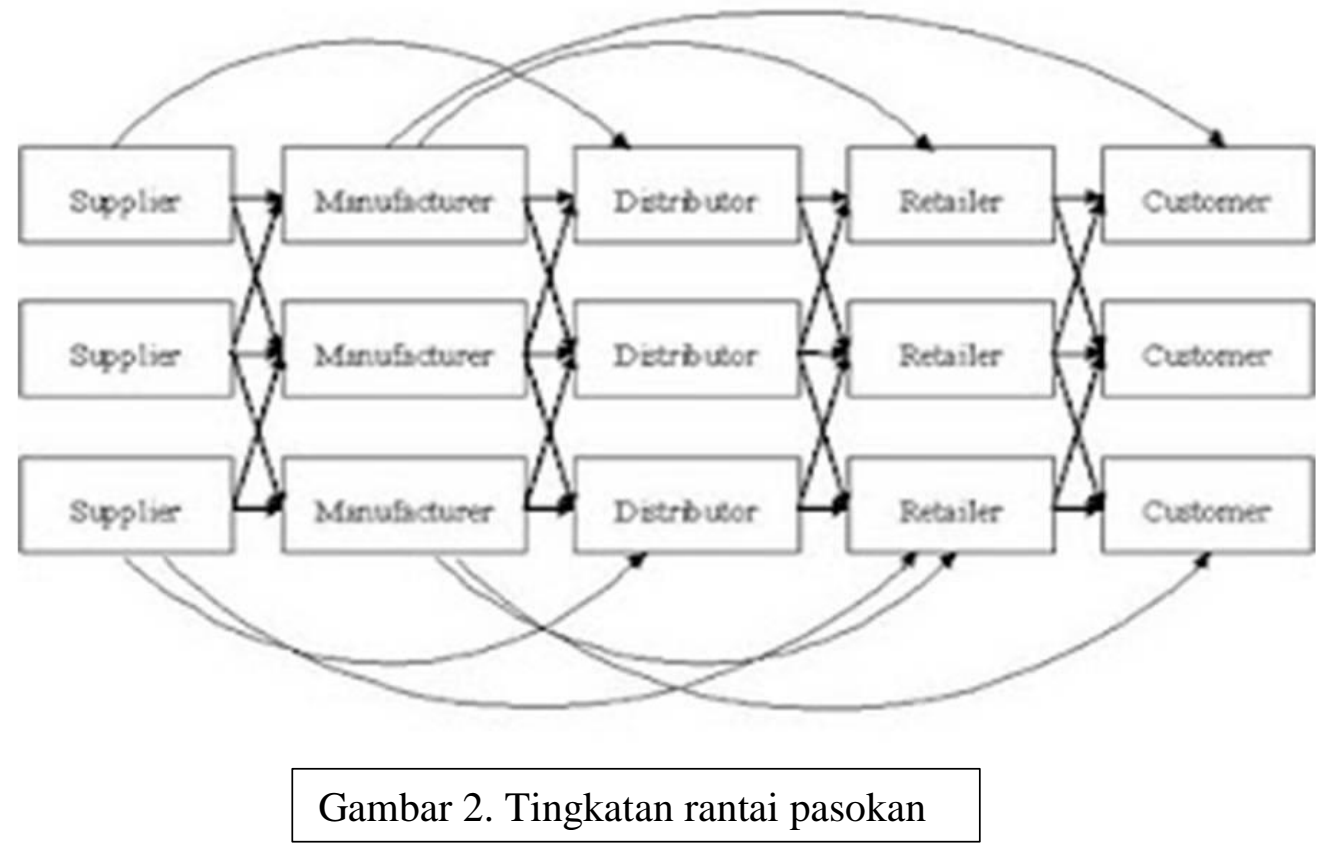

\section{Teknik analisis data}

Analisis deskriptif dilakukan untuk mengamati fenomena penerapan manajemen rantai pasokan bisnis start up Mahasiswa UC. Teknik Analisis Data Penelitian ini merupakan pendekatan deskriptif eksploratif dalam melakukan analisis permasalahan yang ada. Digunakannya pendekatan deskriptif eksploratif karena sifat penelitian yang ingin mengungkapkan fenomena masalah untuk mengembangkan model manajemen rantai pasokan pada bisnis Startup mahasiswa UC yang diharapkan sehingga sesuai dengan hasil yang ingin dicapai. Penelitian ini juga menggunakan model analisis interaktif. Teknik analisis data model interaktif (Miles \& Huberman dalam Herdiansyah, 2012) terdiri atas empat tahapan yang harus dilakukan. Tahapan pertama adalah tahap pengumpulan data, 
tahapan kedua adalah tahap reduksi data, tahapan ketiga adalah tahap display data, dan tahapan keempat adalah tahapan penarikan kesimpulan dan/atau tahap verifikasi. Tahapan-tahapan tersebut akan dijelaskan sebagai berikut:

1) Pengumpulan data.

Proses pengumpulan data dalam penelitian ini dilakukan dengan wawancara dan dokumentasi kepada pemilik bisnis Startup mahasiswa Universitas Ciputra. Wawancara yang dilakukan dikampus maupun diluar kampus dengan menetapkan kesesuaian waktu temu.

2) Reduksi data dengan pembuatan koding dan kategori.

Inti dari reduksi data adalah proses penggabungan dan penyeragaman segala bentuk data yang diperoleh menjadi satu bentuk tulisan (script) yang akan dianalisis. Cara yang dapat ditempuh adalah dengan membaca semua transkrip kemudian di koding yaitu meringkas, menonjolkan, pesan, menangkap esensi dari hasil wawancara yang selanjutnya dikelompokkan ke dalam kategori. Kategori dipilih berdasarkan hasil koding yang memiliki kesamaan tema. Dalam penelitian ini akan dilakukan koding untuk jumlah saluran distribusi pelaku rantai pasokan, misalnya supplier - pabrik - konsumen.

3) Display data.

Display data adalah mengolah data setengah jadi yang sudah seragam dalam bentuk tulisan dan sudah memiliki alur tema yang jelas. Display data disajikan dalam bentuk naratif sesuai dengan tujuan penelitian. Display penelitian ini berupa model rantai pasokan dengan berbagai jumlah pelaku yang terlibat dalam rantai pasokan. Demikian juga display penelitian ini akan menunjukkan strategi manajemen rantai pasokan dari segi persediaan barang dari berbagai supplier.

4) Kesimpulan atau Verifikasi.

Kesimpulan atau verifikasi merupakan tahap terakhir dalam rangkaian analisis data kualitatif menurut model ini. Kesimpulan dalam rangkaian analisis data kualitatif ini yaitu menyimpulkan hasil penelitian dengan membandingkan pertanyaan peneliti dengan hasil penelitian.

\section{HASIL DAN PEMBAHASAN}

Penelitian dilakukan kepada 30 bisnis start up milik mahasiswa UC dengan jenis usaha khusus food and beverages. Responden yang diwawancarai adalah pemilik bisnis sehingga mereka menguasai proses produksi sampai ke tangan konsumen. Dari hasil wawancara kepada 30 bisnis start up milik mahasiswa Universitas Ciputra diperoleh berbagai kombinasi jumlah pemasok tiap perusahaan. Tabel 1 di bawah ini menggambarkan nama usaha dan jenis usaha bisnis start up dan jumlah pemasok yang digunakan untuk menyediakan bahan baku.

Tabel 1. Jenis usaha dan jumlah pemasok pada bisnis Start up

\begin{tabular}{|l|l|l|c|}
\hline No & \multicolumn{1}{|c|}{ Nama bisnis } & \multicolumn{1}{c|}{ Jenis usaha } & $\begin{array}{c}\text { Jumlah } \\
\text { pemasok }\end{array}$ \\
\hline 1 & Batagor Cak Salim & Batagor & 3 \\
\hline 2 & De Cartof & Kentang olahan & 4 \\
\hline 3 & Mega food & Sambal & 3 \\
\hline 4 & Dapur Mustika & Bumbu nasi goreng & 5 \\
\hline 5 & Dapur Kuno & Bumbu dapur & 3 \\
\hline 6 & Dapur Pandawa & Nasi kuning & 5 \\
\hline 7 & Wei Siao & Nasi teriyaki & 5 \\
\hline 8 & Con Resta & Rombong & 2 \\
\hline 9 & Kambingers & Kambing & 3 \\
\hline 10 & Chicken Tong & Ayam Panggang & 4 \\
\hline
\end{tabular}




\begin{tabular}{|l|l|l|c|}
\hline 11 & Pork Station & Nasi goreng daging olahan & 4 \\
\hline 12 & Adelart & Pia & 3 \\
\hline 13 & Cilor & Cireng isi & 2 \\
\hline 14 & Dogadoe & Gado gado & 2 \\
\hline 15 & Amandeu & Susu Almon & 3 \\
\hline 16 & Jember Seafood & Makanan jadi seafood & 2 \\
\hline 17 & Smulen & Pia & 2 \\
\hline 18 & Miruku soda & Minuman soda & 2 \\
\hline 19 & Pokpiah & Pok Pia & 2 \\
\hline 20 & The Rempah & Teh dan susu & 4 \\
\hline 21 & Fries Company & Kentang gorng & 4 \\
\hline 22 & Piri piri & Makanan pedas & 5 \\
\hline 23 & Panna Cotta & Pudding & 2 \\
\hline 24 & Soebalo & Soto & 4 \\
\hline 25 & Pipop copi & Siomay & 3 \\
\hline 26 & Pao Pao & Bakpao & 3 \\
\hline 27 & Solisi & Bakso Isi & 4 \\
\hline 28 & Milk Union & Susu & 3 \\
\hline 29 & Hapie & Pie Susu & 4 \\
\hline 30 & Zone & Pie & \\
\hline
\end{tabular}

Sumber: Data internal, 2017

Dari hasil diatas di peroleh bahwa semua bisnis startup memiliki sumber pemasok bervariasi mulai dari $2-5$ supplier. Pemasok yang menyediakan bahan baku berasal dari pasar terdekat, supermarket dan warung terdekat. Hal ini menunjukkan bahwa pemilik bisnis start up mendapatkan bahan baku bukan dari supplier awal (pertama), namun pemilik bisnis start up mendapatkan bahan baku dari distributor besar dan distributor kecil yang ada di pasar dan supermarket. Artinya ada rantai pasokan yang masih panjang yang terjadi di pasar. Namun dalam penelitian ini, mata rantai pemasok di batasi hanya pada pemasok atau penyedia produk bagi bisnis start up. Persentasi jumlah pemasok start up bisnis dapat dilihat pada tabel 2 di bawah ini.

Tabel 2. Jumlah pemasok startup bisnis

\begin{tabular}{|c|c|l|}
\hline $\begin{array}{l}\text { Jumlah } \\
\text { pemasok }\end{array}$ & Jumlah & Persentase \\
\hline 2 & 8 & $26,7 \%$ \\
\hline 3 & 9 & $30 \%$ \\
\hline 4 & 8 & $26,7 \%$ \\
\hline 5 & 5 & $16,6 \%$ \\
\hline Total & 30 & $100 \%$ \\
\hline
\end{tabular}

Sumber : Data internal, 2017

Pemilik start up bisnis paling banyak menggunakan 3 pemasok mencapai $30 \%$. Sedangkan pemilik start up bisnis paling sedikit menggunakan 5 pemasok hanya 16,6\%. Setelah membeli bahan baku dari pemasok, selanjutnya kegiatan yang dilakukan yaitu melakukan proses produksi (manufaktur atau pabrik) dari bahan baku menjadi produk jadi. Kemudian diikuti dengan kegiatan pemasaran dengan mendistribusikan atau menyalurkan barang kepada konsumen. Pemasaran produk yang dilakukan oleh pemilik bisnis start up melalui berbagai saluran distribusi yang dapat di lihat pada tabel 3 di bawah ini. 
Tabel 3. Saluran distribusi yang digunakan Bisnis Start Up

\begin{tabular}{|l|c|c|}
\hline \multicolumn{1}{|c|}{ Saluran distribusi } & Jumlah & \% \\
\hline $\begin{array}{l}\text { Pemasok - Produsen - Konsumen } \\
\text { Pemasok - Produsen }- \text { Pengecer - Konsumen }\end{array}$ & 14 & $46,7 \%$ \\
\hline Pemasok - Produsen - Konsumen & 13 & $43,3 \%$ \\
\hline Pemasok - Produsen - Pengecer - Konsumen & 2 & $6,7 \%$ \\
\hline Pemasok - Distributor - Pengecer - Konsumen & 1 & $3,3 \%$ \\
\hline \multicolumn{1}{|c|}{ Total } & $\mathbf{3 0}$ & $\mathbf{1 0 0 \%}$ \\
\hline
\end{tabular}

Sumber : data internal, 2017

Pada tabel 3 diatas, pelaku kegiatan ekonomi yang di garis bawahi adalah pemilik bisnis start up. Sebesar 46,7 \% bisnis Start up menggunakan 2 saluran distribusi secara bersamaan, artinya pemilik bisnis start up sebagai produsen atau pembuat produk yang di pasarkan langsung ke konsumen dan melalui pengecer lalu ke konsumen. Presentasi terendah saluran distribusi sebesar 3,3\% menggunakan pada pemilik bisnis sebagai distributor kemudian menjual ke pengecer.

Berdasarkan hasil identifikasi maka ada 3 (tiga) model manajemen rantai pasokan yang sudah diimplementasikan oleh bisnis start up mahasiswa UC yaitu:

\section{Model 1 :}

(2 - 5) Pemasok - Manufaktur - Konsumen

Model manajemen rantai pasokan yang pertama yaitu bisnis start up menggunakan variasi 2-5 pemasok kemudian melakukan proses manufaktur dengan membuat produk dan langsung menjualnya kepada konsumen.

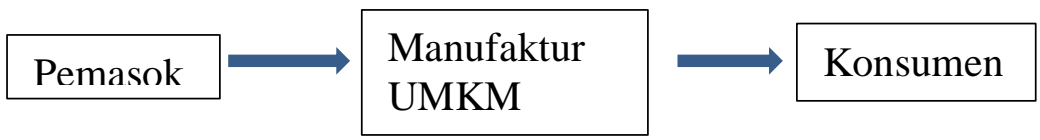

\section{Gambar 3. Model ke - 1 MRP}

\section{Model 2 :}

(2-5) Pemasok - Manufaktur - Pengecer - Konsumen

Model Manajemen rantai pasokan yang kedua yaitu bisnis start up menggunakan 2-5 pemasok kemudian melakukan proses manufaktur dengan membuat produk dan menjualnya ke pengecer, akhirnya sampai ke konsumen.

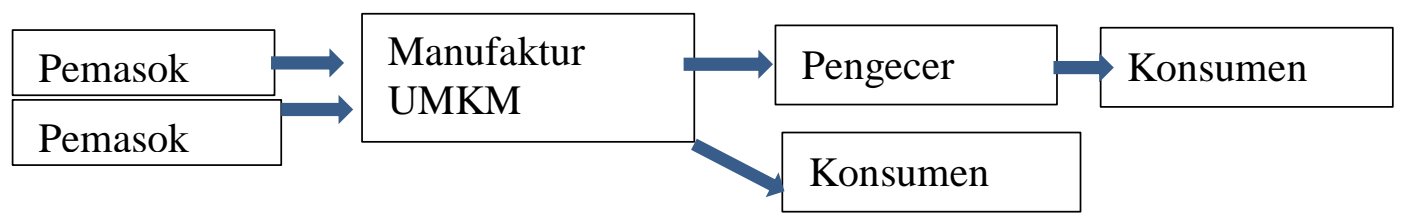

Gambar 4. Model ke - 2 MRP

\section{Model 3 :}

Pemasok-Distributor-Pengecer - Konsumen

Model Manajemen rantai pasokan yang ketiga yaitu pemilik bisnis start up sebagai distributor dari berbagai pemasok, kemudian dijual ke pengecer dan konsumen. 


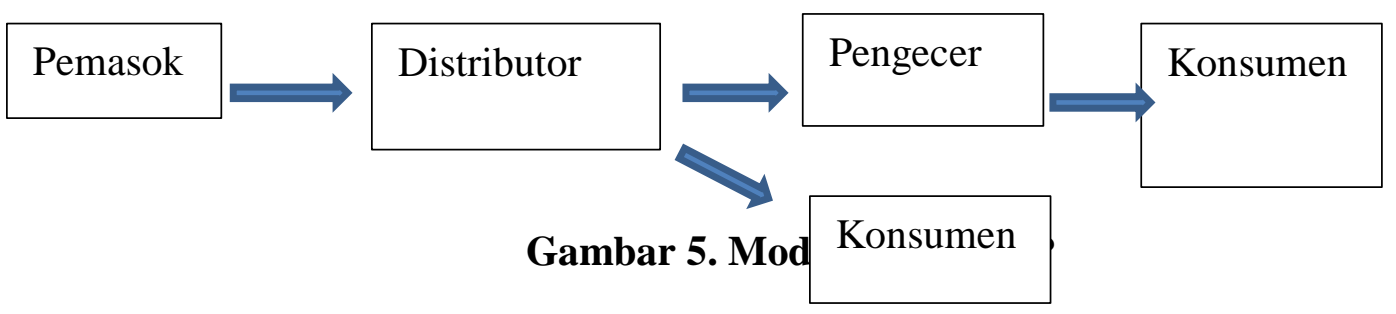

Berdasarkan analisis seperti pada tabel 2 dapat diidentifikasi strategi manajemen rantai pasokan yang digunakan oleh bisnis start up dalam menentukan suplier yaitu:

1. Bisnis start up menggunakan strategi sedikit suplier dengan 2 suplier yaitu $26,6 \%$.

2. Bisnis start up menggunakan strategi sedikit suplier dengan 3 suplier yaitu $30 \%$.

3. Bisnis start up menggunakan strategi sedikit suplier dengan 4 suplier yaitu $26,7 \%$.

4. Bisnis start up menggunakan strategi banyak suplier dengan 5 suplier yaitu $16,6 \%$.

\section{Berbagai permasalahan manajemen rantai pasokan yang telah di implementasikan bisnis Start up.}

Karakteristik bisnis start up pada umumnya adalah:

a) Dalam penyediaan bahan baku, pemilik bisnis start up membeli dari pasar, toko dan supermarket yang dekat. Pemilihan pemasok tersebut dikaitkan dengan kemudahan menjangkau bahan baku kemudian dilanjutkan dengan harga yang paling murah.

b) Seharusnya pemilik bisnis startup mempunyai jaringa ke pemasok asal karena pembelian bahan baku dari pemasok toko, pasar dan supermarket lebih mahal dibandingkan pembelian bahan baku dari pemasok asal.

c) Pengetahuan pemasaran produk dan pengetahuan teknologi harus dimiliki pemilik bisnis start up karena berkaitan dengan distribusi produk mereka ke tangan konsumen.

\section{KESIMPULAN DAN SARAN}

\section{Kesimpulan}

Model manajemen rantai pasokan yang sudah diimplementasikan oleh bisnis start up mahasiswa Universitas Ciputra yaitu:

$$
\begin{aligned}
& \text { Model } 1 \text { : Suplier - Manufaktur - Konsumen } \\
& \text { Model } 2 \text { : Suplier - Manufaktur - pengecer - Konsumen } \\
& \text { Model } 3 \text { : Suplier - Distributor - Pengecer - Konsumen }
\end{aligned}
$$

Strategi manajemen rantai pasokan yang digunakan oleh pemilik bisnis start up dalam menentukan suplier yaitu:

1. Bisnis start up menggunakan strategi sedikit suplier dengan 2 suplier yaitu $26,6 \%$.

2. Bisnis start up menggunakan strategi sedikit suplier dengan 3 suplier yaitu $30 \%$.

3. Bisnis start up menggunakan strategi cukup banyak suplier dengan 4 suplier yaitu $26,7 \%$. 
4. Bisnis start up menggunakan strategi banyak suplier dengan 5 suplier yaitu $16,6 \%$.

\section{Saran}

1. Pihak Inkubator Universitas Ciputra dan pemilik bisnis start up bisnis bekerja sama dalam membangun jaringan informasi berkaitan dengan penyediaan bahan baku dari supplier.

2. Pemerintah kota Surabaya dapat membantu usaha mikro kecil dan menengah bisnis start up dalam memangkas biaya mata rantai pasokan yang semakin besar.

\section{REFERENSI}

Bungin, B. 2014. Penelitian Kualitatif: Komunikasi, Ekonomi, Kebijakan Publik, dan Ilmu Social Lainnya. Edisi kedua. Cetakan ke 7. Prenada Media Group, Jakarta.

Chopra, Sunil Dan Peter Meindl, 2004. Supply Chain Management: Strategy, Planning and Operations. Second Edition. Prentice Hall Inc., Upper Saddle River, New Jersey

David Mc Clure, 2012. Start up metric, Linkedln Learning.

Fajarwati, 2015. Model Manajemen Rantai pasokan pada usaha kecil dan menengah di Yogyakarta.http://repository.umy.ac.id. Diakses tanggal 30 Februari 2017.

Fitzsimmons, James A. dan Mona J. Fitzsimmons, 2006. Service Manajemen. International Edition. Edisi 5. NewYork: The McGraw-Hill.

Heizer, Jay. Dan Reinder, Barry. 2005. Prinsip-prinsip Manajemen Operasi. PT. Salemba. Jakarta.

Indrajit, Richardus Eko dan Djokopranoto, 2003. Konsep Manajemen Supply Chain: Strategi Mengelola anajemen Rantai Pasokan Bagi Perusahaan Modern diIndonesia, PT Gramedia Widiasarana.

Miles, Mattew B \& A Michael Huberman, 2007. Analisis Data Kualitatif, Buku sumber tenang metode metode baru. Jakarta: Universitas Indonesia Press.

Pingkan O.E. Talumewo, Lotje Kawet, Jessy J. Pondaag, 2014. Analisis Rantai pasokan ketersediaan bahan baku di Industri jasa makanan cepat saji pada KFC Multimart Ranotana, Jurnal Emba Vol 2 No 3, Talumewo.

Shapiro, 2006. Modeling the supply chain, Cengage learning, 2nd edition.

Sugiyono. 2011. Metode Penelitian Bisnis:Pendekatan Kuantitatif, Kualitatif dan R\&D. Penerbit Alfabeta. Bandung. 